\title{
Mesenchymal Stem Cells Reduce Left Ventricular Mass in Rats with Doxorubicin-Induced Cardiomyopathy
}

\author{
Las Células Madre Mesenquimales Reducen la Masa Ventricular Izquierda \\ en Ratas con Miocardiopatía Inducida por Doxorrubicina
}

Ali Evren Haydardedeoglu; Deva Basak Boztok Özgermen \& Orhan Yavuz

HAYDARDEDEOGLU, A. E.; BOZTOK ÖZGERMEN, D. B. \& YAVUZ, O. Mesenchymal stem cells reduce left ventricular mass in rats with doxorubicin-induced cardiomyopathy. Int. J. Morphol., 36(1):48-53, 2018.

SUMMARY: Doxorubicin is a drug that used by a majority in the treatment of carcinomas. The most obvious known side effect is cardiomyopathy. Many studies have been carried out to eliminate side effects of the doxorubicin, and stem cell studies have been added in recent years. In this study, it was aimed to investigate fetal-derived mesenchymal stem cells (F-MSCs) treatment of doxorubicininduced cardiomyopathy by morphological methods. A total of 24 rats which were divided into three separate groups (Control, sham, treatment), each consisting of 8 male rats were used. In sham and treatment group, Adriamycin was administered in a single dose by tail injection to perform cardiotoxicity. In the treatment group, F-MSCs were intra-peritoneally administrated. Then, rats were euthanized and their hearts were photographed at the level of papillary muscle. and thickness, diameters and surface area levels were measured. Left ventricular mass (LVM) and left ventricular mass index (LVMI) were calculated after measurement. The sham group, LVM and LVMI levels were found to significantly lower $(\mathrm{p}<0.05)$ than control and treatment group. In the one hand, LVMI levels of rats in treatment group was statistically similar ( $>0.05$ ) to control group. Similarly, LVM levels of control and treatment groups were close to each other while this level of sham group was lower. It has been shown that F-MSC administrations in rats with doxorubicin-induced cardiomyopathy have adverse effect on LVM and LVMI values. In addition, the intra-peritoneal MSC administrations may be an alternative to other injection routes such as intra-venous and intra-cardiac administrations.

KEY WORDS: Adriamycin; Heart; Morphometry; Pluripotent stem cell.

\section{INTRODUCTION}

Doxorubicin is a popular chemotherapeutic, which has serious side effects on patients having tumor. Cardiotoxicity is the most important side effect and it was noted for the first time when children developed heart failure. In cases where doxorubicin-induced cardiotoxicity develops, mild clinical symptoms such as changes in blood pressure, electrocardiography are observed in the patients. In addition, it may also be encountered with severe clinical symptoms such as congestive heart failure, arrhythmia, myocarditis, pericarditis, and cardiomyopathy. Determination of the role of free radical and antioxidant enzymes in the pathogenesis of doxorubicin-induced cardiotoxicity has encouraged antioxidant treatment trials (Wojtacki et al., 2000). In the first study to prevent doxorubicin-induced cardiotoxicity, Van Vleet \& Ferrans (1980) revealed that in rabbits having doxorubicin-induced cardiotoxicity administration of antioxidants such as selenium and Vitamin E reduced the cardiotoxicity in a ten-week trial.

Recently, as used for the cure of many diseases, treatment of cardiac diseases by the use of stem cells for the treatment of certain damages has been accelerated (Kasama et al., 2007; Garbade et al., 2008; Ichim et al., 2008). Stem cells can transform themselves into different cells in the organism, have the ability to survive as long as they are alive, and are self-regenerating cells (Dreesen \& Brivanlou, 2007; Andrades et al., 2011). Stem cells are classified into two groups according to their origin; embryonic stem cells and adult stem cells. The cells obtained from the inner cell mass of the blastocyst in the embryo are called embryonic stem cells. Cells that are not undifferentiated in a differentiated tissue and can be transformed into specific cells of the organ 
that are called adult stem cells. These cells are also called somatic stem cells and under special conditions, they can also become cell types of other tissues. In many organs, especially bone marrow, there are cells that can proliferate and differentiate when necessary. On the other hand, fetal stem cells obtained from fetuses also have characteristics of adult stem cells (Andrades et al.). Mesenchymal stem cells (MSC) were first described by Friedenstein et al. (1976), and are adult-type and main cells of the connective tissue. MSCs can be obtained from many tissues and transformed into different cells such as fat, cartilage, bone, muscle, neuron (Andrades et al.). The most important feature of MSCs is to prevent the tissue damage by the growth factors and cytokines that they contain. MSCs are an appropriate and effective method for the treatment of cellular damage by these features (Pittenger \& Martin, 2004).

In this study, we aimed to treat doxorubicin-induced cardiomyopathy in rats by intraperitoneal administration of fetal-derived Mesenchymal stem cells (F-MSCs) and to morphometrically demonstrate the repair of heart damage. It has been reported in many studies that the use of MSC has the potential to protect against many diseases. However, the intraperitoneal effect of F-MSCs in Doxorubicin-induced cardiomyopathies has not been studied previously.

\section{MATERIAL AND METHOD}

Experiment and Groups. This study was approved by the Local Ethics Committee of Diskapı Yildirım Beyazıt Education and Research Hospital Animal Experiments was granted by Aksaray University Scientific Research Projects.

The materials of this study were 8 weeks-old, male, Sprague-Dawley rats obtained from Diskapı Yıldırım Beyazit Training and Research Hospital Experimental Animal Laboratory. All animals were kept under standard laboratory conditions $\left(21 \pm 2{ }^{\circ} \mathrm{C}\right.$ temperature, $65 \%$ humidity and 12 hours light / 12 hours dark). Ad libitum feeding and continuous water access were provided.

Thirty healthy Sprague-Dawley rats, eight-week-old, male, weighing $(200 \pm 20) \mathrm{g}$ were purchased from Dis ${ }_{s}$ kap1 Training and Research Hospital Laboratory Animal Facility. All animals were maintained in an air-conditioned room at a constant temperature $21 \pm 2^{\circ} \mathrm{C}$ with a $12 \mathrm{~h}$ light/dark cycle, and allowed ad libitum access to water and standard rat chow.

The rats were randomly assigned to three groups ( 8 rats in each group). Rats in group 1 (control group) received no intervention; rats in groups 2 and 3 received tail vein injections of Adriamycin (ADR, Adriablastina; Deva Ilaç ${ }^{\circledR}$ ) $2.5 \mathrm{mg} / \mathrm{kg}$ on day 1 and $4 \mathrm{mg} / \mathrm{kg}$ on day 21 . Rats in group 2 (sham group) received $1 \mathrm{ml}$ sterile saline solution via intraperitoneal injection on days 7,14 and 21 after the last ADR injection, while rats in group 3 (treatment group) received 2x106 F-MSCs through peritoneal cavity injection on days 7,14 and 21 after the last ADR injection.

Morphometric Method. Rats in each group were killed at 8 weeks to evaluate the effect of F-MSCs on ADR-induced cardiomyopathy. Rats were euthanized by decapitation under xylazine/ketamine general anaesthesia, and their body weights were measured. Following necropsy, all hearts were fixed in $10 \%$ neutral formalin solution and cross-sections were taken from the level of papillary muscle and photographs of the cross-section of hearts in all groups were taken (Canon EOS 500D). The left ventricular posterior wall thickness (LVPT), left ventricular lumen diameter (LVLD), interventricular septum thickness (IVST), right ventricular wall thickness (RVT), cut surface cranio-caudal diameter (CCD), cut surface latero-lateral diameter (LLD), cut surface area (CSA), left ventricular area (LVA) and right ventricular area (RVA) were measured according to Kershaw et al. (2012) and Özdemir et al. (2014) in all groups (Digimizer Image Analysis version 4.6.1) (Figs. 1 - 2). The Left ventricular mass (LVM) and left ventricular mass index (LVMI) values were determined according to Devereux \& Reichek (1977). Body surface area (BSA) value was calculated according to Erer \& Kiran (2005).

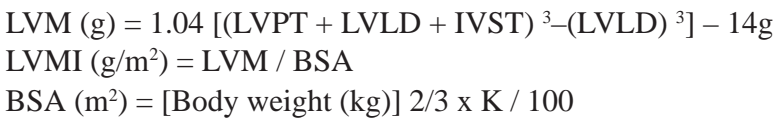

The $K$ value is a special factor and is considered 9 for rats (Erer \& Kiran).

Statistical Analyses. Statistical analyses were performed by the IBM $^{\circledR}$ SPSS $^{\circledast}$ Statistics Version 22 program. The significance level among the study groups was determined by ANOVA and Duncan tests, and $\mathrm{p}<0.05$ was considered to be the accepted value of the differences between the groups.

\section{RESULTS}

The results of the morphometric measurements are given in Table I.

There was no significant difference among IVST (Fig. 3 ) and CCD (Fig. 4) values in all groups ( $>>0.05$ ). The 

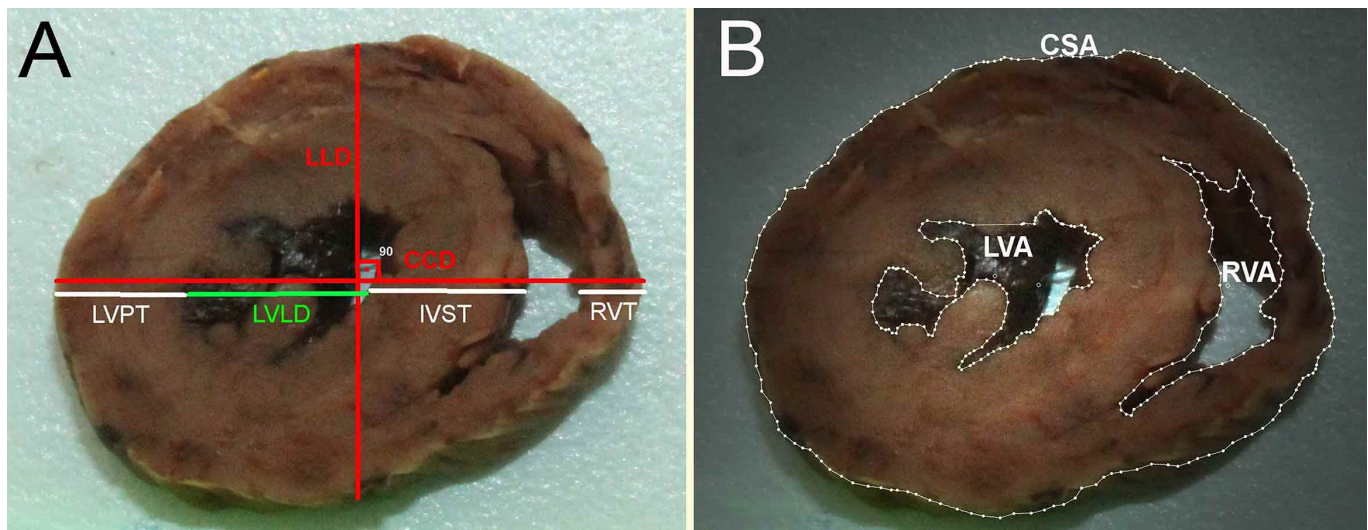

Fig. 1.A. Morphometric measuring points, (mm). LVPT: Left ventricular posterior wall thickness, LVLD: Left ventricular lumen diameter, IVST: Inter-ventricular septum thickness, RVT: Right ventricular wall thickness, CCD: Cut surface cranio-caudal diameter, LLD: Cut surface latero-lateral diameter. B. Morphometric measurement areas, (mm2). CSA: Cut surface area, LVA: Left ventricular area, RVA: Right ventricular area.

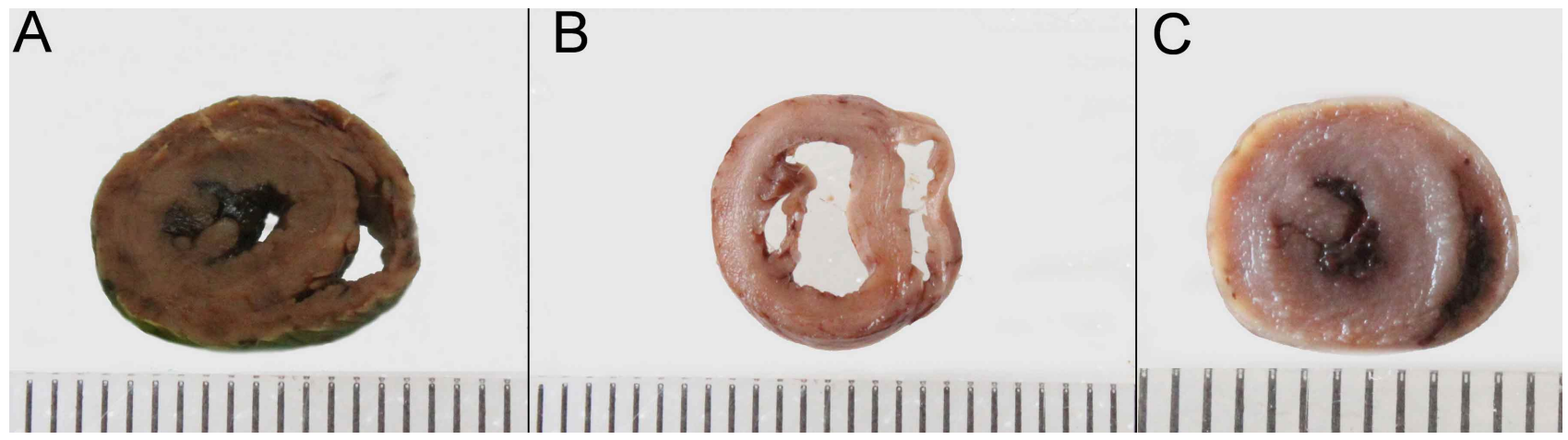

Fig. 2. A. Control group. B. sham group. C. Treatment group.

Table I. Morphometric measurement results and distribution by groups.

\begin{tabular}{cccc}
\hline Measureme nt & Control & Sham & Treatment \\
\hline LVPT (mm) & $2.895 \pm 0.146 \mathrm{~b}$ & $2.278 \pm 0.089^{\mathrm{a}}$ & $2.450 \pm 0.073 \mathrm{a}$ \\
LVLD (mm) & $3.545 \pm 0.467 \mathrm{ab}$ & $4.851 \pm 0.503^{\mathrm{b}}$ & $2.956 \pm 0.423 \mathrm{a}$ \\
IVST (mm) & $2.426 \pm 0.185 \mathrm{a}$ & $1.990 \pm 0.124^{\mathrm{a}}$ & $2.221 \pm 0.164 \mathrm{a}$ \\
RVT (mm) & $1.078 \pm 0.033 \mathrm{~b}$ & $0.815 \pm 0.038^{\mathrm{a}}$ & $0.903 \pm 0.052 \mathrm{a}$ \\
CCD (mm) & $11.097 \pm 0.325^{\mathrm{a}}$ & $9.855 \pm 0.508^{\mathrm{a}}$ & $10.815 \pm 0.352 \mathrm{a}$ \\
LLD (mm) & $10.647 \pm 0.229 \mathrm{~b}$ & $9.624 \pm 0.457^{\mathrm{b}}$ & $9.526 \pm 0.258 \mathrm{a}$ \\
CSA (mm²) & $98.863 \pm 3.295 \mathrm{~b}$ & $76.945 \pm 3.486^{\mathrm{a}}$ & $85.353 \pm 3.800 \mathrm{a}$ \\
LVA (mm $\left.\mathbf{m m}^{\mathbf{b}}\right)$ & $11.348 \pm 2.126^{\mathrm{ab}}$ & $16.150 \pm 2.630^{\mathrm{b}}$ & $7.319 \pm 1.816 \mathrm{a}$ \\
RVA (m m $\mathbf{2})$ & $5.348 \pm 1.450 \mathrm{ab}$ & $9.428 \pm 1.790^{\mathrm{b}}$ & $3.492 \pm 0.438 \mathrm{a}$ \\
LVM (mg) & $692.766 \pm 98.940^{\mathrm{b}}$ & $435.746 \pm 55.725 \mathrm{a}$ & $664.488 \pm 78.213 \mathrm{~b}$ \\
LVMI (g/m2) & $19.666 \pm 2.830 \mathrm{~b}$ & $12.335 \pm 1.544^{\mathrm{a}}$ & $18.816 \pm 2.223 \mathrm{~b}$ \\
\hline
\end{tabular}

Lower case letters on the same line indicate a statistically significant difference between $a, b$, and ab marked numbers $(\mathrm{p}<0.05)$. LVPT: left ventricular posterior wall thickness; LVLD: left ventricular lumen diameter; IVST: interventricular septal thickness; RVT: right ventricular thickness; CCD: cut surface cranio-caudal diameter; LLD: cut surface latero-lateral diameter; CSA: cut surface area; LVA: Left ventricular area; RVA: Right ventricular area; LVM: left ventricular mass; LVMI: left ventricular mass index. 


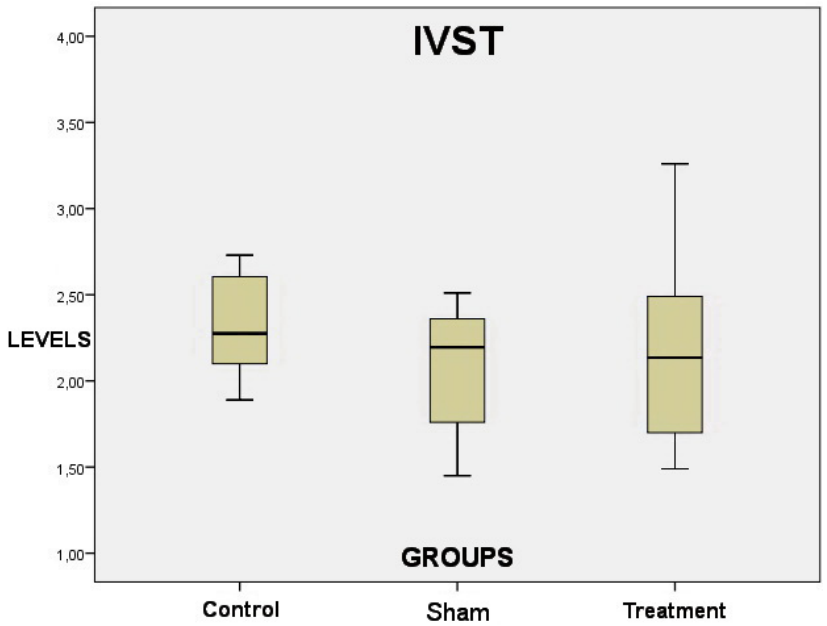

Fig. 3. IVST (mm). Inter-ventricular septum thickness. The difference between groups ( $\mathrm{p}<0.05)$.

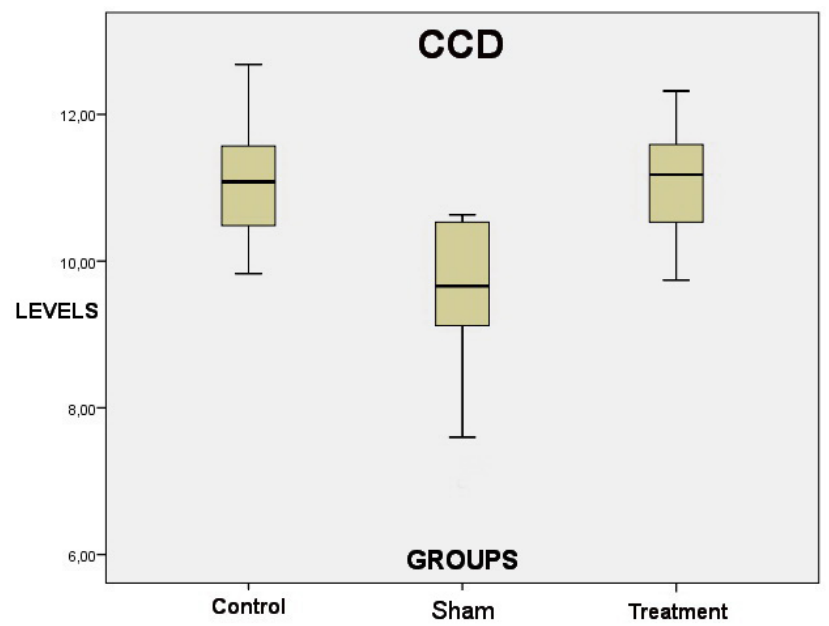

Fig. 4. CCD (mm). Cut surface cranio-caudal diameter. The difference between groups $(\mathrm{p}<0.05)$.

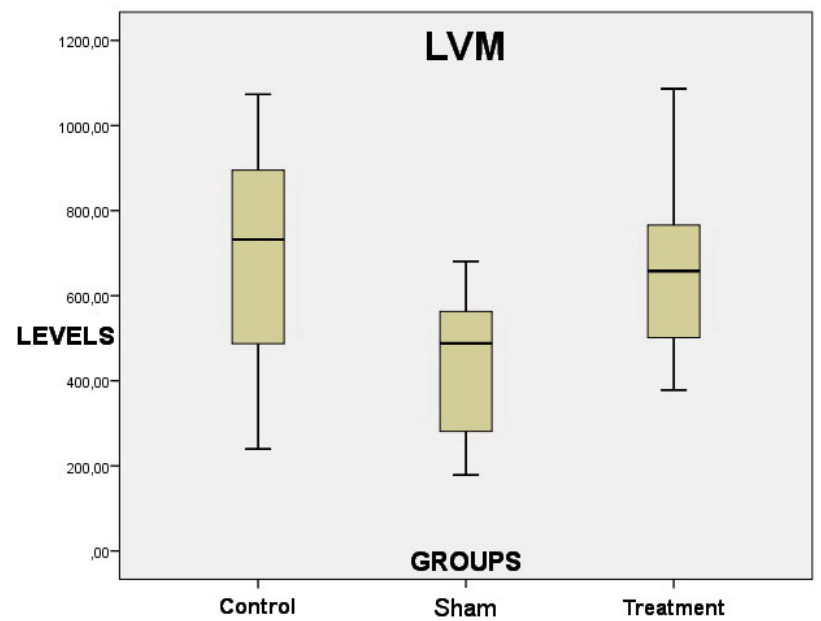

Fig. 5. LVM (mg). Left Ventricular Mass. The difference between groups $(\mathrm{p}<0.05)$.

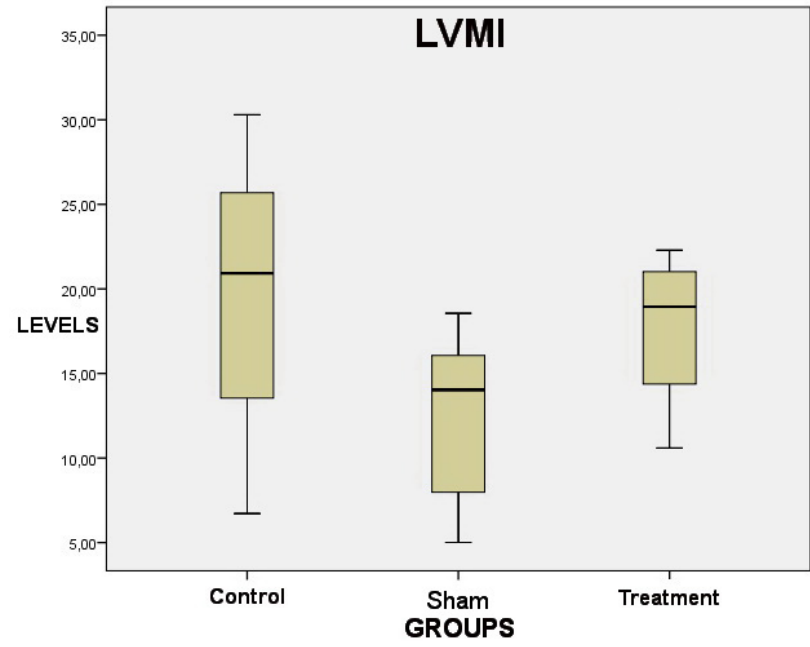

Fig. 6. LVMI $\left(\mathrm{g} / \mathrm{m}^{2}\right)$. Left Ventricular Mass Index. The difference between groups $(\mathrm{p}<0.05)$.

statistical similarity was observed between control and treatment groups in LVM (Fig. 5) and LVMI (Fig. 6) (p> 0.05 ), while in sham group these values were different from other groups $(\mathrm{p}<0.05)$.

When the values of LVPT, RVT, and CSA were taken into account, sham and treatment groups were statistically different ( $p>0.05)$, whereas values of control group were different from each other ( $\mathrm{p}<0.05)$. LVLD, LLD, LVA and RVA values showed statistically significant difference between all groups $(\mathrm{p}<0.05)$.

\section{DISCUSSION}

Doxorubicin is an antibiotic drug of the anthracycline group, mostly used in the treatment of carcinomas. Among the cumulative side effects, dilated cardiomyopathy (DCM) is the most known feature (Gava et al., 2013). According to Nagaya et al. (2005), it has been observed that myocardial infarction is stimulated by myogenesis and angiogenesis through MSC transplantation in DCM cases. MSCs are convenient and effective methods for the treatment of cellular damage by their growth factors and cytokines (Pittenger \& Martin). Angert et al. (2011) reported that the number of $\mathrm{BrdU}+$ myocytes increased in cardiac-damaged cats, and it is indicating that this could be a signal of regeneration in the heart.

Morphometric methods are frequently used to reveal certain disorders in the heart (Lushnikova et al., 2004; Nart et al., 2004; Kershaw et al.). Foppa et al. (2005) stated that 
the most objective method of determining LVM value is performing an autopsy. Devereux \& Reichek formulated LVM and LVMI values, and shed light on the work done in this area. In this study, morphometric methods were used to investigate the changes took place when F-MSCs were administered for cardiac regeneration in the hearts of Doxorubicin-induced male rats.

Neilan et al. (2012) stated that LVMI may be an indicator for DCM. In their study, they emphasized that the LVMI in DCM patients was decreased. In the present study, LVMI value of sham group is lower than control group. On the contrary, the LVMI value of rats in group treatment was close to control group. Similarly, when LVM values are taken into account, it was noticed that the values of control and treatment groups were close to each other while this value of sham group was lower.

Onmaz et al. (2011) have shown that LVPT, LVLD, IVST values are among the measured values for DCM diagnosis in echocardiographic examinations. However, in dogs with DCM, LVPT and IVST values were decreased with respect to normality and LVLD value was increased with ECG results. Similarly, Momiyama et al. (1994) reported that LVLD levels were significantly increased in patients with DCM compared with normal patients, suggesting that they lead to LV hypertrophy. In the present study, it was determined that the LVPT and IVST values of the rats in the sham group were significantly lower than the Control group, while the LVLD value was increased. It was found that the values in the treatment group were close to the Control group, but not exactly reached in the value of the Control group. Shake et al. (2002) reported that LVPT values were similar to healthy animals in intra-cardiac (IC) administered MSC treatment to pigs with myocardial infarction. However, Pittenger \& Martin stated that MSC applications can be performed intra-venously (IV) or IC, and that the route of administration may affect the treatment.

Tidholm \& Jönsonn (2005) reported that enlargement of both ventricular areas (LVA and RVA) in dogs with DCM in gross examinations. In this study, when the areas of the left and right ventricles were evaluated, the LVA and RVA values of the sham group were significantly higher than those of the Control group. However, the fact that these values of the treatment group were statistically different from the sham group, and suggests that the F-MSCs may have a positive effect on ventricular areas.

When MSCs were administered intravenously, it was noted that they passed into the marrow cavity from circulation in the healthy animals (Saito et al., 2002). However, MSCs applied during events such as ischemia or reperfusion were found to be circulating first, followed by cardiac tissues in high amounts. Pittinger \& Martin (2004) emphasized that the most of the MSCs return to the bone marrow when MSC treatment is delayed by about 2 weeks after the cardiac injury even if administered intravenously. In this study, unlike the other investigators, after intra-peritoneal (IP) MSC applications, LVM and LVMI values in the treatment group were statistically similar to the control group $(\mathrm{P}>0.05)$. This suggests that IP MSC administrations may give positive results in DCM cases.

As a result, MSCs applied to reduce the effects of doxorubicin-induced DCM in rats were considered to have a positive morphometric effect on LVM and LVMI values in the heart. However, it was concluded that the curative effect was not sufficient in terms of the above-mentioned other values. In addition, it is concluded that the administration of MSCs as IP may be an alternative to IV and IC administrations.

HAYDARDEDEOGLU, A. E.; BOZTOK ÖZGERMEN, D. B. \& YAVUZ, O. Las células madre mesenquimales reducen la masa ventricular izquierda en ratas con miocardiopatía inducida por doxorrubicina. Int. J. Morphol., 36(1):48-53, 2018.

RESUMEN: La doxorrubicina es un medicamento usado ampliamente en el tratamiento de carcinomas. El efecto secundario más conocido es la miocardiopatía. Se han llevado a cabo muchos estudios para eliminar los efectos secundarios de la doxorrubicina, y en los últimos años se han agregado estudios con células madre. mediante métodos morfológicos, se intentó investigar el tratamiento de las células madre mesenquimales (F-MSCs) derivadas del feto, de la miocardiopatía inducida por doxorrubicina. Se utilizó un total de 24 ratas que se dividieron en tres grupos (control, simulación, tratamiento), cada uno de las cuales consistía en 8 ratas macho. En el tratamiento simulado y en el grupo tratamiento, se administró doxorrubicina en una dosis única mediante inyección en la cola de la rata para realizar cardiotoxicidad. En el grupo tratamiento, las FMSC se administraron intraperitonealmente. Luego, las ratas fueron sacrificadas y sus corazones fueron fotografiados a nivel de los músculos papilares, y se midieron los espesores, los diámetros y los niveles de área superficial. Después de las mediciones se calcularon la masa ventricular izquierda (MVI) y el índice de masa ventricular izquierda (IMVI). En el grupo simulado, los niveles de MVI y IMVI se encontraron significativamente inferiores $(\mathrm{p}<0.05)$ que en los grupos control y tratamiento. Por un lado, los niveles de IMVI de las ratas en el grupo de tratamiento fueron estadísticamente similares ( $>$ > 0,05) al grupo de control. De forma similar, los niveles de MVI de los grupos control y tratamiento se aproximaban uno al otro, mientras que este nivel era más bajo en el grupo simulado. Se ha demostrado que la administracion de F-MSC en ratas con miocardiopatía inducida por doxorrubicina tiene un efecto adverso sobre los valores de MVI y IMVI. Además, la administracion de MSC intraperitoneal puede ser una alternativa a otras rutas de inyección tal como las administración intravenosa e intracardíaca.

PAlabras ClaVe: Adriamicina; Corazón; Morfometría; Célula madre pluripotente, 


\section{REFERENCES}

Andrades, J. A.; Claros, S.; Jiménez-Palomo, P.; López-Puerta, J. M.; Zamora-Navas, P.; Guerado, E.; Monleón, M.; Araque, M. C. \& Becerra, J. Skeletal regeneration by mesenchymal stem cells: What else? In: Eberli, D. (Ed.). Regenerative Medicine and Tissue Engineering - Cells and Biomaterials. London, InTech, 2011. pp.107-44.

Angert, D.; Berretta, R. M.; Kubo, H.; Zhang, H.; Chen, X.; Wang, W.; Ogorek, B.; Barbe, M. \& Houser, S. R. Repair of the injured adult heart involves new myocytes potentially derived from resident cardiac stem cells. Circ. Res., 108(10):1226-37, 2011.

Devereux, R. B. \& Reichek, N. Echocardiographic determination of left ventricular mass in man. Anatomic validation of the method. Circulation, 55(4):613-8, 1977.

Dreesen, O. \& Brivanlou, A. H. Signaling pathways in cancer and embryonic stem cells. Stem Cell Rev., 3(1):7-17, 2007.

Erer, H. \& Kiran, M. M. Veterinary Oncology. Konya, Bahcivanlar Publishers, 2005

Foppa, M.; Duncan, B. B. \& Rohde, L. E. Echocardiography-based left ventricular mass estimation. How should we define hypertrophy? Cardiovasc. Ultrasound, 3:17, 2005.

Friedenstein, A. J.; Gorskaja, J. F. \& Kalugina, N. N. Fibroblast precursors in normal and irradiated mouse hematopoietic organs. Exp. Hematol., 4(5):267-74, 1976.

Garbade, J.; Schubert, A.; Barten, M.J.; Aupperle, H.; Arsalan, M.; Borger, M.A.; Jacobs, S.; Dhein, S. \& Mohr, F.W. Stem cell transplantation modulates mRNA gene expression profile in doxorubicin-induced cardiomyopathy. J. Stem Cells, 3:235-44, 2008.

Gava, F. N.; Zacché, E.; Ortiz, E. M.; Champion, T.; Bandarra, M. B.; Vasconcelos, R. O.; Barbosa, J. C. \& Camacho, A. A. Doxorubicin induced dilated cardiomyopathy in a rabbit model: an update. Res. Vet. Sci., 94(1):115-21, 2013

Ichim, T. E.; Solano, F.; Brenes, R.; Glenn, E.; Chang, J.; Chan, K. \& Riordan, N. H. Placental mesenchymal and cord blood stem cell therapy for dilated cardiomyopathy. Reprod. Biomed. Online, 16(6):898-905, 2008.

Kasama, S.; Toyama, T.; Hatori, T.; Sumino, H.; Kumakura, H.; Takayama, Y.; Ichikawa, S.; Suzuki, T. \& Kurabayashi, M. Evaluation of cardiac sympathetic nerve activity and left ventricular remodelling in patients with dilated cardiomyopathy on the treatment containing carvedilol. Eur. Heart J., 28(8):989-95, 2007.

Kershaw, O.; Heblinski, N.; Lotz, F.; Dirsch, O. \& Gruber, A. D. Diagnostic value of morphometry in feline hypertrophic cardiomyopathy. J. Comp. Pathol., 147(1):73-83, 2012.

Lushnikova, E. L.; Klinnikova, M. G.; Molodykh, O. P. \& Nepomnyashchikh, L. M. Morphological manifestations of heart remodeling in anthracyclineinduced dilated cardiomyopathy. Bull. Exp. Biol. Med., 138(6):607-12, 2004

Momiyama, Y.; Mitamura, H. \& Kimura, M. ECG characteristics of dilated cardiomyopathy. J. Electrocardiol., 27(4):323-8, 1994.

Nagaya, N.; Kangawa, K.; Itoh, T.; Iwase, T.; Murakami, S.; Miyahara, Y.; Fujii, T.; Uematsu, M.; Ohgushi, H.; Yamagishi, M.; Tokudome, T.; Mori, H.; Miyatake, K. \& Kitamura, S. Transplantation of mesenchymal stem cells improves cardiac function in a rat model of dilated cardiomyopathy. Circulation, 112(8):1128-35, 2005.

Nart, P.; Williams, A.; Thompson, H. \& Innocent, G. T. Morphometry of bovine dilated cardiomyopathy. J. Comp. Pathol., 130(4):235-45, 2004.

Neilan, T. G.; Coelho-Filho, O. R.; Pena-Herrera, D.; Shah, R. V.; JeroschHerold, M.; Francis, S. A.; Moslehi, J. \& Kwong, R. Y. Left ventricular mass in patients with a cardiomyopathy after treatment with anthracyclines. Am. J. Cardiol., 110(11):1679-86, 2012.

Onmaz, A.C.; Kibar, M.; Günes, V.; Atasever, A. \& Atalan, G. Clinic, radiologic, electrocardiographic and echocardiographic findings in two dogs with dilated cardiomyopathy. Saglık Bilimleri Dergisi, 20(3):247$55,2011$.
Özdemir, Ö.; Yavuz, O. \& Hatipoglu, F. Effect of routine pathological procedure on morphometric parameters of the heart in rat models. Sci. Res. Essays, 9(8):224-8, 2014.

Pittenger, M. F. \& Martin, B. J. Mesenchymal stem cells and their potential as cardiac therapeutics. Circ. Res., 95(1):9-20, 2004.

Saito, T.; Kuang, J. Q.; Bittira, B.; Al-Khaldi, A. \& Chiu, R. C. Xenotransplant cardiac chimera: immune tolerance of adult stem cells. Ann. Thorac. Surg., 74(1):19-24, 2002.

Shake, J. G.; Gruber, P. J.; Baumgartner, W. A.; Senechal, G.; Meyers, J.; Redmond, J. M.; Pittenger, M. F. \& Martin, B. J. Mesenchymal stem cell implantation in a swine myocardial infarct model: engraftment and functional effects. Ann. Thorac. Surg., 73(6):1919-25, 2002.

Tidholm, A. \& Jönsson, L. Histologic characterization of canine dilated cardiomyopathy. Vet. Pathol., 42(1):1-8, 2005.

Van Vleet, J. F. \& Ferrans, V. J. Clinical and pathologic features of chronic adriamycin toxicosis in rabbits. Am. J. Vet. Res., 41(9):1462-9, 1980.

Wojtacki, J.; Lewicka-Nowak, E. \& Lesniewski-Kmak, K. Anthracyclineinduced cardiotoxicity: clinical course, risk factors, pathogenesis, detection and prevention-review of the literature. Med. Sci. Monit., 6(2):411-20, 2000.

Corresponding author:

Orhan Yavuz, DVM, PhD

Aksaray University

Faculty of Veterinary Medicine

Department of Pathology

Aksaray

TURKEY

Email: vetorhanyavuz@gmail.com

Received: 21-07-2017

Accepted: 13-10-2017 